Ewa Kotecka

Uniwersytet Łódzki

\title{
KONSULTACJE SPOKECZNE I REFERENDUM JAKO FORMY PARTYCYPACJI SPOKECZNEJ W SPRAWOWANIU WŁADZY SAMORZĄDOWEJ
}

\section{Zagadnienia wstępne}

Konstytucja RP ma znaczenie jako generalna podstawa do tworzenia ustaw zawierających przepisy określające tematykę i formy dialogu społecznego. Jednakże ogólność sformułowań ujętych w Konstytucji ogranicza bezpośredniość stosowania jej przepisów do dialogu społecznego podczas procesu legislacyjnego i dyskusji społecznej nad oceną skutków regulacji. Art. 4 ust. 2 Konstytucji formułując zasadę suwerenności Narodu, stanowi, że władzę Naród sprawuje przez swoich przedstawicieli lub bezpośrednio decyduje w swoich sprawach oraz jest twórcą prawa i organów państwowych, legitymizując ich działalność. Także Europejska Karta Samorządu Terytorialnego (dalej EKST) ${ }^{1}$ zawiera postanowienia nakładające na sygnatariuszy tego dokumentu obowiązek konsultowania ze wspólnotami lokalnymi o tyle, o ile jest to możliwe, we właściwym czasie i w odpowiednim trybie, wszelkich spraw związanych z procesem planowania i podejmowania decyzji bezpośrednio dotyczących tych wspólnot. Wartym zauważenia jest fakt, że EKST w pierwszej kolejności wymienia bezpośrednie formy realizacji prawa obywateli do decydowania o sprawach publicznych. Polski ustawodawca uregulował te zagadnienia odwrotnie, ustanawiając $w$ art. 11 ust. 1 u.s.g., iż mieszkańcy gminy podejmują rozstrzygnięcia w głosowaniu powszechnym lub za pośrednictwem organów gminy.

W państwach demokratycznych prawo obywateli do kierowania i zarządzania sprawami publicznymi stanowi jedną z podstawowych zasad ustrojowych. Prawo do uczestnictwa w kierowaniu sprawami publicznymi jest istotnym elementem syste- 
mu praw człowieka². Należy ono do kategorii wolności i praw politycznych. Prawo to zostało również expressis verbis wskazane w Międzynarodowym Pakiecie Praw Obywatelskich i Politycznych (art. 25) ${ }^{3}$. Istotą tradycyjnie pojmowanych praw człowieka jest to, że przysługują one jednostce niezależnie od aktów prawa pozytywnego; prawo pozytywne ich nie ustanawia, powinno natomiast je uznawać ${ }^{4}$ W literaturze spotkać można poglądy kwalifikujące wspólnotę mieszkańców jako organ administracji publicznej, jednak M. Kasiński nie podziela tych poglądów. Stoi on na stanowisku, iż de lege lata nie ma możliwości ani potrzeby uznania wspólnoty mieszkańców jako osobnego organu samorządowego w sensie prawnym ${ }^{5}$. Według autora wspólnota jest pierwotnym podmiotem samorządu, realizującym swoją władzę uczestnicząc np. w referendum. W doktrynie zachodniej, w szczególności francuskiej i amerykańskiej, na określenie prawa do uczestniczenia w życiu publicznym sensu largo częstokroć używa się terminu „prawo do partycypacji”6. Zgodnie z definicją, jaką posługuje się Instytut Spraw Publicznych, partycypacja to bezpośrednie i pośrednie, sformalizowane i niesformalizowane, indywidualne i zbiorowe uczestnictwo obywateli w podejmowaniu i wykonywaniu decyzji dotyczących dobra wspólnego ${ }^{7}$. Partycypacja społeczna zakłada uczestnictwo mieszkańców w projektowaniu i podejmowaniu rozstrzygnięć mających wpływ na funkcjonowanie tej społeczności właściwie pod każdym względem: społecznym, ekonomicznym, gospodarczym, kulturowym, zdrowotnym czy środowiskowym, a tym samym zaangażowanie jednostki w proces decyzyjny, który może mieć charakter rozstrzygający jak referendum lub opiniujący jak konsultacje. Punktem wyjścia dla rozważań partycypacji społecznej jako formy sprawowania władzy jest postulat utworzenia partycypacyjnego modelu administracji publicznej. W modelu tym akcentuje się nie tyle aspekt efektywności ekonomicznej działania administracji, co raczej aspekt demokratyzacji - udziału w działaniu administracji zarówno jego bezpośrednich wykonawców (urzędników niższej rangi), jak i potencjalnych adresatów i beneficjentów działania administracji publicznej ${ }^{8}$.

Konsultacje społeczne ${ }^{9}$ służą urzeczywistnianiu wizji społeczeństwa obywatelskiego oraz stanowią prawo do uczestniczenia w życiu publicznym. Ustawodawca nigdzie nie zawarł definicji legalnych konsultacji społecznych, a ich regulacje prawne są rozproszone. W pierwszej kolejności należy wskazać Konstytucję, w której ustawodawca nie zawarł wprost wymogu przeprowadzenia konsultacji społecznych,

2 samorządowych w świetle dyrektywy Rady 94/80/WE, ST 2006, nr 1-2, s. 5. Dz.U. z 1977 r. Nr 38, poz.167.

E. Olejniczak-Szałowska, Prawo do udziału w referendum lokalnym. Rozważania na tle ustawodawstwa polskiego, Łódź 2002, s. 25.

M. Kasiński, Monizm i pluralizm władzy lokalnej, Łódź 2009, s. 282.

E. Olejniczak-Szałowska, Prawo do udziału w referendum lokalnym..., op. cit., Łódź 2002, s. 24-25.

A. Olech, Modele Partycypacji w sprawowaniu władzy, Warszawa 2010.

M. Stefaniuk, Działanie administracji publicznej w ujęciu nauk administracyjnych, Lublin 2009, s. 408

E. Kotecka, [w:] Współdziałanie w samorządzie terytorialnym, Łódź 2012, s. 30 i n. 
ale wynika to z zasad konstytucyjnych. W doktrynie wielu autorów definiuje konsultacje w różny sposób, choć pojęcia te sprowadzają się do podobnych wniosków. E. Olejniczak-Szałowska określa konsultacje społeczne w JST jako formę uczestnictwa członków wspólnoty samorządowej w kierowaniu sprawami publicznymi polegającą na wyrażaniu i przekazywaniu opinii na temat projektu rozstrzygnięcia poddanego procesowi konsultacyjnemu zainicjowanemu przez organ, w którego kompetencji mieści się załatwienie spraw danego rodzaju. ${ }^{10} \mathrm{Z}$. Niewiadomski uważa, iż konsultacje mają stanowić swoistego rodzaju rekompensatę za brak możliwości stosowania współcześnie demokracji bezpośredniej i jest tzw. „demokracją uczestniczącą", wykraczającą poza gramatyczne brzmienie przepisu. ${ }^{11} \mathrm{~J}$. Wylężałek prezentuje pogląd, iż istotą konsultacji społecznych jest przepływ opinii pomiędzy dwoma rodzajami podmiotów - organami podejmującymi decyzje (podmioty konsultujące) a globalnymi i częściowymi społecznymi podmiotami władzy (podmioty konsultowane $)^{12}$. W. Durka zauważa, że występowanie komunikacji zwrotnej pozwala na uniknięcie wielu konfliktów i przyspiesza proces decyzyjny, a w poszukiwaniu optymalnego rozwiązania duże znacznie może mieć wiedza mieszkańców o występujących problemach, a także we wcześniejszych sposobach ich rozwiąza$\operatorname{nia}^{13}$.

W Polsce tryb konsultacji nie został określony ustawowo, dlatego można spotkać różne ich formy, ${ }^{14} \mathrm{np}$. stron $\mathrm{www}^{15}$ (niezbędne jest utworzenie forum ${ }^{16}$ ), głosowania, wysłuchania publicznego, cyklu bezpośrednich spotkań ${ }^{17}$, ankiet, konkursu z nagrodami, spotkania parkowego, spacerów miejskich, konferencji (jednak możliwe są one do zastosowania na bardzo zaawansowanym etapie konsultacji, wówczas należy je traktować jedynie jako podsumowanie wszystkich wcześniejszych etapów). Oryginalną formą konsultacji są Warsztaty Charrette ${ }^{18}$, gdzie pod okiem ekspertów/trenerów każda ze stron przedstawia argumenty za i przeciw, a następnie wypracowuje się stanowiska kompromisowe. Zakres podmiotowy uczestników konsultacji jest bardzo szeroki i zależy w dużej mierze od formy przeprowadzonych konsultacji. Obywatelom UE bez polskiego obywatelstwa przysługuje również prawo udziału w konsultacjach społecznych prowadzonych we wspólnotach samorzą-

\footnotetext{
10 E. Olejniczak-Szałowska, [w:] M. Stahl, B. Jaworska-Dębska (red.), Encyklopedia samorządu terytorialnego dla każdego. Ustrój, Warszawa 2010, s. 87-88.

11 Z. Niewiadomski, [w:] R. Hauser, Z. Niewiadomski (red.), Ustawa o samorządzie gminnym. Komentarz z odniesieniami do ustaw o samorządzie powiatowym i samorządzie województwa, Warszawa 2011, s. 66. J. Wylężałek, Kilka uwag w sprawie pojęcia konsultacji społecznej, PiP 1982, nr 1-2, s. 70. W. Durka, [w:] Z. Zychowicz (red.), Konsultacje społeczne w samorządzie terytorialnym, Szczecin 2011, s. 13. E. Kotecka, [w:] Współdziałanie w samorządzie terytorialnym, op. cit., s. 33-35. www.konsultacje.um.warszawa.pl UM Łodzi http://forum.samorzad.lodz.pl jednak z tej możliwości nikt nie skorzystał. W Lesznie w 2001 r. odbyły się konsultacje w celu wydania opinii w sprawie połączenia Leszna z powiatem leszczyńskim. Uchwała nr XXXIV/359/2001.

18 9-11.02.2011 r. Organizatorami warsztatów był UM w Dąbrowie Górniczej oraz Śląski Związek Gmin i Powiatów (www.silesia.org.pl. Także Ruda Śląska przeprowadziła warsztaty Charrette 8-10.06.2011 r., gdzie omawiany był Lokalny Program Rewitalizacji, www.esil.pl
} 
dowych szczebla gminnego ${ }^{19}$. Na tle omawianych zagadnień pojawił się dylemat - czy rada gminy w uchwale w sprawie zasad i trybu przeprowadzania konsultacji z mieszkańcami może określić, że mają prawo brać w nich udział wyłącznie osoby posiadając czynne prawo wyborcze do rady gminy? Zdecydowanie należy negatywnie ocenić takie podejście, bowiem okoliczność, iż dana osoba jest pozbawiona praw publicznych bądź ubezwłasnowolniona (nie posiada praw wyborczych) nie jest pozbawiona statusu mieszkańca gminy. Przepisy mieszkańca utożsamiają z osobą stale zamieszkującą na terenie danej gminy, a nie osobą posiadającą pełnię praw. Takie stanowisko zajął także WSA wywodząc, że rada nie ma delegacji do zawężenia kręgu osób uprawnionych do wzięcia udziału w konsultacjach tylko do mieszkańców posiadających pełnię praw wyborczych ${ }^{20}$.

Niezależnie od tego, czy konsultacje mają charakter obligatoryjny czy fakultatywny, to rozstrzygnięcie danej sprawy bez uprzedniego przeprowadzenia obligatoryjnych konsultacji stanowi naruszenie prawa. Jak zauważa M. Mączyński, można sobie wyobrazić taką sytuację, że z przyczyn niezależnych od mieszkańców, np. technicznych, organizacyjnych - konsultacje nie zostaną przeprowadzone, a w związku z tym organ stanowiący nie może podjąć skutecznej uchwały w sprawie wyrażenia swojego stanowiska co do opinii (bezwzględne wymaganie wcześniejszego przeprowadzenia konsultacji), art. 4a ust. 3, zaś uznaje to wymaganie wbrew interesowi społeczności lokalnej - za spełnione ${ }^{21}$.

\section{Relacje pomiędzy instytucją referendum i konsultacji}

Jak zauważa M. Stahl, można odnieść wrażenie, że ani rada, ani mieszkańcy nie rozróżniają konsultacji społecznych i instytucji referendum, instytucji odrębnych na płaszczyźnie prawnej i mających odmienne cele. ${ }^{22}$ NSA w wyroku z 21 lipca 1999 r. ${ }^{23}$ podniósł, że sprawy, które są ustawowo zastrzeżone na rzecz organów gminy nie mogą być przedmiotem referendum rozstrzygającego, a wynik referendum przeprowadzonego $\mathrm{w}$ takiej sprawie może być traktowany jedynie w kategoriach konsultacji społecznych. W wyroku NSA z 1 lutego 2001 r. ${ }^{24}$ sąd orzekł, że aby rozstrzygnięcie dokonane przez mieszkańców w drodze referendum gminnego mogło być realizowane $\mathrm{z}$ wiążącym skutkiem dla sprawy, musi się ono mieścić w zakresie zadań i kompetencji gminy. Jak dalej wywodzi sąd, przyjęcie innego stanowiska doprowadziłoby do naruszenia właściwości organu. Jak wywodzi

\footnotetext{
19 E. Olejniczak-Szałowska, Prawo do uczestnictwa w kierowaniu sprawami publicznymi..., op. cit., s. 11.

20 Wyrok z 12 czerwca 2006r. II SA/Op 207/06.

21 M. Mączyński, [w:] P. Chmielnicki (red.), Ustawa o samorządzie gminnym. Komentarz, Warszawa 2010, s. 103.

22 B. Jaworska-Dębska, [w:] M. Stahl (red.), Prawo administracyjne, pojęcia, instytucje, zasady w teorii i orzecznictwie, Warszawa 2009, s. 364.

IV SA 2452/98, Lex 47300 (niepubl.).

24 II SA 2817/00, Lex Polonica nr 2085225.
} 
NSA w postanowieniu z 29 czerwca 1993 r. $^{25}$ przedmiotem referendum gminnego nie może być opiniodawcze stanowisko rady gminy lub innego jej organu, wypowiedziane w sprawie nie należącej do zakresu działania gminy. Fakt, że ustawodawca nie określa formy konsultacji, stanowiąc jedynie, że zasady i tryb określa rada gminy w drodze uchwały może sugerować, że konsultacje mogą mieć dowolną formę, tymczasem konsultacje nie mogą przyjąć formy referendalnej. Na tle omawianych zagadnień pojawiły się doktrynalne wątpliwości, czy gminy mogą przeprowadzić referendum w sprawie zmiany granic zaproponowanej przez Radę Ministrów w sytuacji, gdy ustawa nakazuje przeprowadzenie konsultacji oraz czy w przypadku tworzenia jednostek pomocniczych możliwe jest przeprowadzenie referendum zamiast konsultacji? Początkowo zdecydowanie przeważał pogląd, że de lege lata w sprawie tego rodzaju nie może być przeprowadzone referendum, bowiem opiniodawczy charakter konsultacji wykluczał możliwość przeprowadzenia referendum, które ma wiążący charakter ${ }^{26}$. Odmienne stanowisko zajął $\mathrm{TK}^{27}$ wywodząc, że przedmiotem referendum może być każda sprawa dotycząca wspólnoty mieszkańców, niezastrzeżona do wyłącznej kompetencji organów władz publicznych innych niż samorządowe - referendum opiniodawcze także w przypadkach, w których ustawodawca przewiduje przeprowadzenie konsultacji. Dlatego też nakaz zawarty w art. $170 \mathrm{w}$ zbiegu z art. 163 Konstytucji, a skierowany do ustawodawcy należy rozumieć jako nakaz dopuszczenia referendum, wyrażającego wolę mieszkańców wszędzie tam, gdzie mogą oni współkształtować proces decyzyjny, dotyczący istotnej sprawy danej wspólnoty - choćby nie mogli oni przesądzać całkowicie o sposobie załatwienia sprawy. W związku ze stanowiskiem TK ustawodawca znowelizował przepisy i wprowadzono 4 rodzaj referendum. W dodanym art. 4c u.s.g. wprowadzono zapis, zgodnie z którym w sprawie zmiany granic może być przeprowadzone referendum lokalne z inicjatywy mieszkańców, wówczas konsultacji społecznych nie przeprowadza się. R. Szarek twierdzi, iż w świetle naszego prawa instytucja „referendum gminne" uplasowała się wyżej od konsultacji z mieszkańcami, ${ }^{28}$ a brak przeciwwskazań ustawowych co do przeprowadzenia referendum gminnego czyni dopuszczalnym korzystanie $\mathrm{z}$ tej instytucji nawet w sytuacjach, gdy przepisy szczególne nakazują przeprowadzenie konsultacji. Z podglądem tym nie można się jednak zgodzić, bowiem w przypadku zmiany granic wynik konsultacji nie jest dla Rady Ministrów wiążący, a właśnie taki charakter miałoby referendum gminne. Stanowisko w tej sprawie zajął NSA, który w tezie wyroku z 17 grudnia 2001 r. stwierdził wprost, że skoro w sprawie podziału gminy na dwie mniejsze gminy obligatoryjne jest przeprowadzenie konsultacji z mieszkańcami gminy, to tym samym nie jest 
dopuszczalne przeprowadzenie referendum gminnego ${ }^{29}$. W uzasadnieniu NSA wywiódł, że zgodnie z utrwaloną już linią orzecznictwa, referendum lokalne oraz konsultacje są dwiema oddzielnymi instytucjami prawnymi, których nie można ze sobą utożsamiać ani stosować zamiennie. Nie ma też podstaw prawnych, aby na zasadzie a minori ad maius ${ }^{30}$ domniemywać dopuszczalność przeprowadzenia w takiej sprawie referendum gminnego. Wbrew więc obiegowemu poglądowi, prawo przedmiotowe zawiera kilka zakazów organizowania referendum gminnego. W przypad$\mathrm{ku}$ analizowanym przez omawiany tu wyrok NSA zakaz wynika $\mathrm{z}$ obligatoryjnych konsultacji. Odmienne stanowisko zajął NSA w postanowieniu z 22 września 1995 r. stwierdzając, że mieszkańcy gminy (...) mogą wystąpić do rady gminy z inicjatywą przeprowadzenia referendum gminnego, w sprawie podziału gminy przez utworzenie dwóch nowych gmin ${ }^{31}$.

\section{Obligatoryjność i fakultatywność}

Podzielam pogląd E. Olejniczak-Szałowskiej, że w przypadku konsultacji obligatoryjnych, członek społeczności lokalnej ma prawo do konsultacji, ma nawet prawo żądać, aby podmioty władzy publicznej zasięgały jego opinii oraz brały ją pod uwage przed podjęciem decyzji ${ }^{32}$. Jak dalej wywodzi autorka, istnieją środki prawne służące skutecznemu dochodzeniu tego prawa. Według klasyfikacji publicznych praw podmiotowych przeprowadzonej przez M. Kuleszę, omawiane prawo mieści się $\mathrm{w}$ kategorii praw podmiotowych do współdziałania $\mathrm{z}$ administracją w rozstrzyganiu spraw publicznych ${ }^{33}$. Takie stanowisko zajął także Z. Niewiadomski, twierdząc, że mieszkańcy mają prawo żądania przeprowadzenia konsultacji pod rygorem wadliwości podjętego działania, ale nawet w przypadku konsultacji fakultatywnych odmowa ich przeprowadzenia nie może pozostać poza oceną zainteresowanych, dokonywaną głównie na płaszczyźnie politycznej ${ }^{34}$. Na początku warto podkreślić, iż ustawodawca użył niefortunnego sformułowania, iż w wypadkach przewidzianych ustawą „mogą być przeprowadzane” na terytorium gminy konsultacje z mieszkańcami, co może sugerować ich fakultatywność. Tymczasem, jak słusznie zauważa E. Olejniczak-Szałowska ${ }^{35}$, w wypadkach przewidzianych ustawą konsultacje nie są fakultatywne, lecz obligatoryjne. Konsultacje fakultatywne mogą być

II SAB/Kr 117/01.

Skoro wolno mniej, to tym bardziej wolno więcej, czyli skoro wolno przeprowadzić konsultacje, to tym bardziej dopuszczalne jest referendum gminne.

SA/Wr 2134/95.

E. Olejniczak-Szałowska, [w:] M. Stahl (red.), Prawo administracyjne, pojęcia, instytucje, zasady w teorii i orzecznictwie, Warszawa 2009, s. 364-365.

Ibidem, s. 365.

Z. Niewiadomski, [w:] R. Hauser, Z. Niewiadomski (red.), Ustawa o samorządzie gminnym. Komentarz z odniesieniami do ustaw o samorządzie powiatowym i samorządzie województwa, Warszawa 2011, s. 68.

E. Olejniczak-Szałowska, Konsultacje we wspólnocie samorządowej, ST 1997, nr 1-2, s. 103. 
przeprowadzone na każdym szczeblu samorządu we wszystkich sprawach ważnych dla gminy i jej mieszkańców (art. 5a ust. 1 in fine) oraz wypadkach przewidzianych w ustawie. Kryterium ważności nie zostało nigdzie przez ustawodawcę zdefiniowane. Zatem można uznać, że „ważne” to każde wydarzenie, które stanowi o życiu danej społeczności na danym terenie. O tym, czy sprawa jest ważna dla gminy, decyduje rada gminy. Może to czynić każdorazowo albo w sposób ogólny w wydanych przez siebie przepisach „o zasadach i trybie przeprowadzania konsultacji”36. W wyroku NSA ${ }^{37}$ uznał, iż uprawnienie podmiotu, czy w danej sprawie przeprowadzić konsultacje czy nie, nie jest jednoznaczne z obowiązkiem, oczywiście poza obligatoryjnym zakresem. M. Mączyński zauważa, że to rada gminy ustanawiając zasady i tryb przeprowadzenia konsultacji powinna uwzględnić kryteria, czy sprawa jest ważna dla gminy ${ }^{38}$. Stanowisko w tej sprawie zajął także NSA w postanowieniu z 29 czerwca 2003 r. twierdząc, iż przedmiotem referendum ma być stanowcze rozstrzygnięcie określonej „,sprawy ważnej dla gminy”, a rozstrzygana w ten sposób sprawa musi się mieścić w zakresie właściwości organów gminy ${ }^{39}$.

\section{Wnioski de lege ferenda}

M. Stefaniuk zauważa, że przedmiotem zainteresowania badaczy zajmujących się problemem partycypacji w działaniach administracji publicznej były także jej granice. W tym zakresie ukształtowały się dwa stanowiska. Pierwsze idealistyczne i radykalne - w demokratycznym państwie partycypacja, której celem jest dążenie do samorealizacji obywateli, nie ma granic. Według drugiego stanowiska, bardziej realistycznego, hołdującego przekonaniu, że partycypacja jest raczej formą uzupełnienia mechanizmów demokracji przedstawicielskiej niż samodzielnym i jedynym sposobem podejmowania demokratycznych decyzji, istnieje potrzeba określenia granic tej partycypacji ${ }^{40}$.

Ciekawe propozycje zmian ustawowych wnosi projekt ${ }^{41}$ ustawy o wzmocnieniu udziału mieszkańców $w$ działaniach samorządu terytorialnego, o współdziałaniu gmin, powiatów $i$ województw ${ }^{42}$. Projekt tej ustawy podtrzymuje konieczność istnienia instytucji konsultacji społecznych, a nawet wzmacnia ich pozycje. Wzmocniona tu została pozycja sołectw - ustawa przewiduje explicite, że konsultacje moga polegać na wyrażeniu stanowiska przez zebrania wiejskie (art. 7 ust. 3). Kolejną pro-

\footnotetext{
36 Z. Leoński, Samorząd terytorialny w RP, Warszawa 2006, s. 104.

37 Wyrok NSA z 9.06.2010, II OSK 378/10 Legalis.

38 M. Mączyński, [w:] P. Chmielnicki, Ustawa o samorządzie gminnym. Komentarz, op. cit., s. 108.

39 SA/Wr 935/93, ONSA 1994, nr 3, poz.105.

40 M. Stefaniuk, Działanie administracji publicznej w ujęciu nauk administracyjnych, op. cit., s. 410.

41 Proponowana ustawa jest efektem prac zespołu „Samorząd Terytorialny dla Polski” funkcjonującego w ramach Forum Debaty Publicznej.

42 E. Kotecka, [w:] Współdziałanie w samorządzie terytorialnym, op. cit., s. 50-52.
} 
pozycją jest zapytanie obywatelskie (art. 12 ust. 1) i wysłuchanie obywatelskie, które stanowi de facto szczególny przypadek konsultacji (art. 9 ust. 1). Wprowadzany przez niniejszą ustawę wachlarz nowych narzędzi zwiększających wpływ poszczególnych członków wspólnot samorządowych na decyzje podejmowane przez organy tych wspólnot przełoży się w dłuższej perspektywie na silniejszą partycypację, a co za tym idzie - lepsze urzeczywistnienie idei samorządności.

\section{BIBLIOGRAFIA}

1. Durka W., [w:] Zychowicz Z. (red.), Konsultacje społeczne w samorządzie terytorialnym, Szcze$\operatorname{cin} 2011$.

2. Jaworska-Dębska B., [w:] Stahl M. (red.) Prawo administracyjne, pojęcia, instytucje, zasady w teorii i orzecznictwie, Warszawa 2009.

3. Kasiński M., Monizm i pluralizm władzy lokalnej, Łódź 2009.

4. Kotecka E., [w:] Współdziałanie w samorządzie terytorialnym, Łódź 2012.

5. Leoński Z., Samorząd terytorialny w RP, Warszawa 2006.

6. Mączyński M., [w:] Chmielnicki P. (red.), Ustawa o samorządzie gminnym. Komentarz, Warszawa 2010.

7. Modele Partycypacji w sprawowaniu władzy, A. Olech, Warszawa 2010.

8. Niewiadomski Z., [w:] Hauser R., Niewiadomski Z. (red.), Ustawa o samorządzie gminnym. Komentarz z odniesieniami do ustaw o samorządzie powiatowym i samorządzie województwa, Warszawa 2011.

9. Olejniczak-Szałowska E., [w:] Stahl M. (red.), Prawo administracyjne, pojęcia, instytucje, zasady w teorii i orzecznictwie, Warszawa 2009.

10. Olejniczak-Szałowska E., [w:] Stahl M., Jaworska-Dębska B. (red.), Encyklopedia samorządu terytorialnego dla każdego. Ustrój, Warszawa 2010.

11. Olejniczak-Szałowska E., Konsultacje we wspólnocie samorządowej, ST 1997, nr 1-2.

12. Olejniczak-Szałowska E., Prawo do uczestnictwa w kierowaniu sprawami publicznymi we wspólnotach samorządowych w świetle dyrektywy Rady 94/80/WE, ST 2006, nr 1-2.

13. Olejniczak-Szałowska E., Prawo do udziału w referendum lokalnym. Rozważania na tle ustawodawstwa polskiego, Łódź 2002.

14. Stefaniuk M., Działanie administracji publicznej w ujęciu nauk administracyjnych, Lublin 2009.

15. Szarek R., Konsultacje czy referendum?, „Wspólnota” 1997, nr 28.

16. Wylężałek J., Kilka uwag w sprawie pojęcia konsultacji społecznej, PiP 1982, nr 1-2.

17. Wyrok TK z 26 lutego 2003r., K 30/02, OTK ZU 2003, nr 2A, poz. 16.

18. Wyrok NSA z 9.06.2010, II OSK 378/10 Legalis. 
Konsultacje społeczne i referendum jako formy partycypacji społecznej...

\section{PUBLIC CONSULTATION AND REFERENDUM AS A FORM OF SOCIAL PAR- TICIPATION IN THE EXERCISE OF LOCAL GOVERNMENT}

In this article, the author stresses the importance of participation of people in decision-making at the local government level, highlighting the fact that in democracy the right of citizens to the leadership and management of public affairs is one of the basic principles of the political system. Regardless of what form of legal actions residents take part in, decision-making processes are appropriate and even necessary. In addition, the author appreciates the fact that the catalog of these forms is always growing and changing in favor of the citizens. The author also emphasizes the use of obligatory and facultative referendum, municipal and public consultation, and underlines the fact that under the Polish local goverment law the fundamental differences between these two institutions are their goals, how they are used and the effects they have. Public participation implies the cooperation of citizens in the design and making decisions that affect the functioning of the community, and thus the involvement of individuals in the decision-making process. Such participation should be assessed very positively, because it is not only targeted to investigate the degree of social acceptance for the planned activities of local government, but also is one of the most important forms of social dialogue. In contrast, a small range of cases where the decision is now subject to mandatory consultations should be assessed negatively, as well as the reluctance of the authorities to reach for this type of direct power enforcement. The range of tools to increase the impact of members of the council on the decisions taken by the authorities of those communities will translate into a stronger long-term perspective of participation, and as a result - a better realization of the idea of self-government, which the author has undoubtedly proved.

Key words: municipal referendum, consultation, participation, government, community 